\title{
Relationship between Nutritional Status and Development of Preschool Aged Children in the Operational Area of Puskesmas Batua Raya
}

\author{
Nuraeni Azizah ${ }^{1 *}$, Darmawansyih ${ }^{2}$, Henny Fauziah ${ }^{3}$ \\ ${ }^{1}$ Medicine Education Study Program, Faculty of Medicine and Health Sciences, Alauddin State Islamic \\ University, Makassar, Indonesia \\ ${ }^{2}$ Department of Biochemistry, Faculty of Medicine and Health Sciences, Alauddin State Islamic University, \\ Makassar, Indonesia \\ ${ }^{3}$ Department of Histology, Faculty of Medicine and Health Sciences, Alauddin State Islamic University, \\ Makassar, Indonesia \\ *Corresponding Author. E-mail: nuraeniazizah18@gmail.com Mobile number: +6281248392016
}

\begin{abstract}
ABSTRAT
Introduction: Development is a mental change that occurs gradually and over time, starting from simple abilities to more difficult abilities, such as attitude, behavior and intelligence. Preschool age is a golden age in which all aspects of development play an important role in aspects of further development. The study aimed to determine the relationship between nutritional status and development of preschool aged children in the operational area of Puskesmas Batua Raya.

Methods: The study used a cross sectional study design with total sample of 196 respondents. Data were collected through anthropometric measurements of body weight and KPSP assessment (developmental prescreening questionnaire) was carried out. Data analysis was performed using the chi square test.

Results: Results of the study found that children with appropriate development were higher in good nutritional status $(74 \%)$ than those who were below the nutritional status (5.6\%). Analysis of the two variables shows the value of $\mathrm{p}=0.000$. Statistically, there was a significant relationship between nutritional status and development of preschool children.

Conclusion: Based on the research, it may be concluded that there is a relationship between maternal knowledge and the behavior of exclusive breastfeeding in the operational area of the Sudiang Primary Health Center.
\end{abstract}

Keywords: Nutritional Status; Development; KPSP; Body Weight

Article history:

Received: 12 February 2021 Accepted: 26 April 2021 Published: 30 April 2021

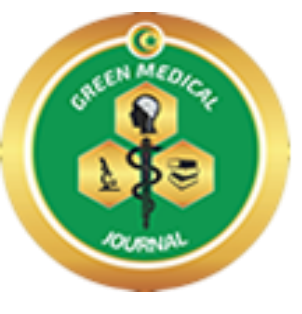

Published by:

Faculty of Medicine

Universitas Muslim Indonesia

Mobile number:

+6282197210007

\section{GREEN MEDICAL JOURNAL \\ E-ISSN 2686-6668}

Address:

Jl. Urip Sumoharjo Km. 5, Makassar

South Sulawesi, Indonesia

Email:

greenmedicaljournal@umi.ac.id 


\section{Introduction}

Developing countries are generally occupied by 200 million children below 5 years old and more than a third of that number does not fulfill their development potential. Failure to fulfill the potential for child development is expected to hamper children ability to receive information and, by that, produce some effects on socializing in the community. Development of children in developing countries is influenced by several factors, namely inadequate early stimulation, severe chronic malnutrition, iron deficiency, anemia, and iodine deficiency. One of the important factors in development is nutritional status in children. Nutritional status is a measure for assessing the fulfillment of children's nutritional needs. Proper and balanced nutritional intake will affect the development, growth and intelligence of children ${ }^{1}$.

According to Hadi (2019), the cost of nutritional status is an effort to interpret all information obtained through anthropometric research, food consumption, biochemistry and clinic. According to WHO in Hadi (2019), the nutritional status monitoring system can be carried out in the form of surveys, surveillance and screening. ${ }^{2}$

Data from the Indonesian Health Profile in 2014 reported that the prevalence between malnutrition and lower-nutrition had showed an increase from 2007 to 2013 on the nutritional status of children under five based on weight index for age (Body Weight / Age), weight for height (Body Weight / Height), and height according to age (height / Age) is obtained. ${ }^{3}$

Nationally, the prevalence of underweight is based on the results of Health Research Regional (Riskesdas) in 2013 was 19.6 percent, consisting of 5.7 percent of malnutrition and 13.9 percent of malnutrition. When compared with the national prevalence rate 2007 (18.4\%) and 2010 (17.9\%) were seen to increase. For the Province South Sulawesi data on Malnutrition + Underweight based on results Riskesdas was $17.6 \%$ (2007) increased to $25 \%$ (2010) and experienced again increase to> 25\% (2013). ${ }^{4}$

The Ministry of Health of the Republic of Indonesia in 2018 reported that the results of measuring the growth and development of children were obtained (3.9\%) who experienced malnutrition, (13.8\%) malnutrition, (79.2\%) good nutrition and (3.1\%) excess nutrition. For the national scale, especially in South Sulawesi Province, namely (4.6\%) experiencing malnutrition, (18.4\%) malnutrition, (74.2\%) good nutrition, and $(2.9 \%)$ overnutrition. ${ }^{5}$

Prevalence of Underweight Children in 2019 by $11 \%$, has exceeded the set target (22\%) and decreased (performance increased) when compared to 2018 (18.10\%). Achievements in 2019 when compared with national achievements still below the national prevalence, namely $17.7 \%$ (performance is higher than national achievements). However, even though South Sulawesi has succeeded reducing the prevalence rate on an ongoing basis is still necessary enhanced efforts that are more optimal in improving nutritional status community, especially in the toddler group. ${ }^{6}$

Preschool age is the golden age where all the aspects of development play an important role in aspects 
of further development. Development of preschool children includes motor, social and language personal development. During the period of child development, there is a needed for guidance to match what is expected. $^{7}$

Providing the proper nutrition can make children experience the right and appropriate development. Child development can be identified using two methods, namely the Denver II method and the KPSP method (Developmental Pre-Screening Questionnaire). As for this study, researchers employed the KPSP method to determine the development of preschool children. This was because the method is considered easier and faster in identifying the observed development cycle of the child. ${ }^{8}$.

Based on the description above, the research was conducted with the aim of identifying the level of nutritional status of children, development of preschool children, and the relationship of nutritional status to the development of preschool children.

\section{Methods}

The study used an analytical method with a cross sectional design. Research design was used to determine the relationship between the dependent variable, namely nutritional status and the independent variable, namely child development. Research was conducted in January 2020 in the operational area of the Batua Raya Community Health Center. The population in this study was all preschool children in the operational area of Puskesmas Batua Raya. The sampling was carried out using non-probability sampling techniques, namely purposive sampling with a total sample of 196 which met the inclusion and exclusion criteria.

Data include primary data and secondary data. Primary data were obtained from direct anthropometric observations and measurements of preschool children and questionnaire assessments. Questionnaire sheet was the instrument used to determine the level of nutritional status on child development. This instrument presented in the form of statements adapted to the determined indicators. Statements can be divided into two, namely negative and positive statements. Secondary data were obtained from preschool age children in the operational area of the Batua Community Health Center. Data analysis was completed by bivariate analysis.

Bivariate analysis is an analysis carried out on two suspected related variables. The relationship of each variable was tested using the test chi square statistic with significance level $(\alpha=0.05)$. The purpose of the chi square test is to test for differences in proportions or percentages between different groups of data.

The data obtained were then analyzed using IBM SPSS 23 software. The analysis used the Chi-Square test to determine the relationship between dependent and independent variables. 


\section{Result}

Result of the research showed that characteristics of the respondents include female respondents of 96 children $(48.9 \%)$ and male of 100 children $(51.1 \%)$. Characteristics of children regarding the gestational age and normal birth weight showed that there were as many as 196 children (100\%) found for this area. There were 148 children with good nutritional status (74.5\%), 8 children with poor nutrition (4.1\%), 39 children with lower nutrition (19.9\%), and 3 children with over nutrition (1.5\%). There were 144 preschool children $(73.5 \%)$ of the total 196 children who were at the appropriate development, while in the doubtful category there were 46 children (23.5\%), and in the deviant category showed 6 children (3.0\%).

Table 1. Distribution of Characteristics of Respondents Based on the Characteristics of Preschool Children (3-5 years) in the operational area of the Batua Raya Community Health Center in $2020(N=196)$

\begin{tabular}{|c|c|c|}
\hline Characteristics & $\mathbf{n}$ & $\%$ \\
\hline \multicolumn{3}{|l|}{ Gender } \\
\hline Male & 100 & 51.1 \\
\hline Female & 96 & 48.9 \\
\hline \multicolumn{3}{|l|}{ Age of Gestation } \\
\hline Normal (37 - 42 Weeks) & 196 & 100 \\
\hline \multicolumn{3}{|l|}{ Birth body weight } \\
\hline Normal birth weight ( $2500-4000$ grams $)$ & 196 & 100 \\
\hline \multicolumn{3}{|l|}{ Nutritional status } \\
\hline Malnutrition & 8 & 4.1 \\
\hline Poor nutrition & 39 & 19.9 \\
\hline Good nutrition & 146 & 74.5 \\
\hline Over nutrition & 3 & 1.5 \\
\hline \multicolumn{3}{|l|}{ Preschool Age Child Development } \\
\hline Appropriate & 160 & 81.6 \\
\hline Doubted & 30 & 15.3 \\
\hline Deviated & 6 & 3.1 \\
\hline
\end{tabular}

Table 1 explained that the respondents include 96 girls (48.9\%), and 100 boys (51.1\%). Respondents who had normal weight gestation were 196 children (100\%). There were 146 children who experienced good nutrition (74.5\%), 8 children (4.1\%) had malnutrition, 39 children (19.9\%) had poor nutrition, and as much as 3 children $(1.5 \%)$ in the category of over nutrition. Also, there were 160 children $(81.6 \%)$ of preschoolers who were in appropriate development from a total of 196 children, while as many as 30 children $(15.3 \%)$ were in doubted category, and 6 children $(3.1 \%)$ were in deviated category. 
Table 2. Relationship between nutritional status and child development.

\begin{tabular}{|c|c|c|c|c|c|c|c|c|c|}
\hline \multirow{3}{*}{ Nutritional Status } & \multicolumn{6}{|c|}{ Development Status } & \multirow{2}{*}{\multicolumn{2}{|c|}{ Total }} & \multirow{3}{*}{ Value } \\
\hline & \multicolumn{2}{|c|}{ Appropriate } & \multicolumn{2}{|c|}{ Doubted } & \multicolumn{2}{|c|}{ Deviated } & & & \\
\hline & $\mathbf{n}$ & $\%$ & $\mathbf{n}$ & $\%$ & $\mathbf{n}$ & $\%$ & $\mathbf{n}$ & $\%$ & \\
\hline Over & 3 & 1.5 & - & - & - & - & 3 & 1.5 & 0.000 \\
\hline Good & 145 & 74 & - & - & 1 & 0.5 & 146 & 74.5 & \\
\hline Poor & 11 & 5.6 & 26 & 13.3 & 2 & 1 & 39 & 19.9 & \\
\hline Malnutrition & 1 & 0.51 & 4 & 2.04 & 3 & 1.53 & 8 & 4.1 & \\
\hline Total & 160 & 81.6 & 30 & 15.3 & 6 & 3.1 & 196 & 100 & \\
\hline
\end{tabular}

Based on Table 2, children who were in the over nutritional status showed development status of $1.5 \%$ (3 respondents). Good nutritional status with an appropriate development status were $74 \%$ (145 respondents), and only $0.5 \%$ (1 respondent) in the deviated category. In the poor nutrition status, there were $5.6 \%$ (11 respondents) at the appropriate development status, $13.3 \%$ (26 respondents) at the doubted, and $1 \%$ ( 2 respondents) in the deviated category. Meanwhile, malnutrition showed $0.5 \%$ ( 1 respondent) was in the appropriate developmental status, $2.04 \%$ ( 4 respondents) in the doubted, and $0.51 \%$ ( 1 respondent) in the deviated category.

\section{Discussion}

Data from the results of research using children in the age period of 3-5 years in the working area of the Batua Raya Community Health Center found that there was a relationship between nutritional status and development of preschool children. This conclusion is in line with that found in the research by Wauran, et.al. (2016) in the study titled the "Relationship Between Nutritional Status and Gross Motor Development of Children aged 1-3 years in Bitung Village, Amurang District, Minahasa Regency," which showed a relationship between nutritional status and gross motor development ${ }^{3}$

Meanwhile, the research was conducted by Kusuma (2013) et al showed that there was no relationship between nutritional status and child development. Based on this research, nutritional status had several factors that affect child development, such as maternal work, and development because their parents leave them for work. ${ }^{9}$

Several reasons that may affect the nutritional status of children include child care patterns, food intake, and infectious diseases. When a child gets enough good food intakes, but often attacked by infectious diseases, their nutritional status will be severely affected. Likewise, children who were provided with inappropriate food may have a weak immune system and, ultimately, affect their nutritional status. Parenting patterns may take the form of attitudes and behavior of mothers or other caregivers in terms of their closeness to children, providing food, caring for, cleanliness, affection and so on ${ }^{10}$. 
In Islam, this has been explained in Q.S An-Nisa / 4: 9

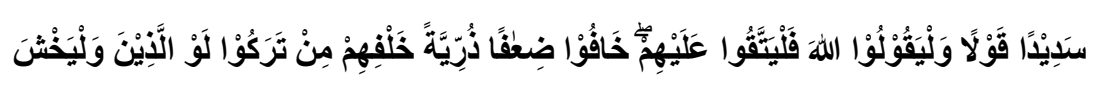

Translation: And, fear Allah those who in case leave behind them weak children, whom they fear for their (welfare), therefore let them fear Allah and let them speak the right word. ${ }^{11}$

According Shibab (2016) in Tafsir Al-Mishbah, the interpretation above explained that "weak children" in this case are weak physically, materially, and mentally. Therefore, Allah SWT forbids us to leave weak children. ${ }^{12}$

In this study, nutritional status was measured using body weight for age. The parameters used to provide an image of body mass are carried out by measuring body weight. Body mass is very sensitive to sudden changes, for example exposure to infectious diseases, decreased appetite, and decreased food consumption. In normal circumstances when there is a balance between consumption and nutritional needs, body weight can develop with age. Conversely, in an abnormal condition there are two possibilities for weight development, namely that it can develop sooner or later than normal. This also affects development. When children are deficient in nutrients, cell division will result in a maximum reduction of brain cells which can result in developmental delays. Providing optimal nutrition will cause development to be appropriate $^{13}$

Development is the increasing ability and function of the body to become more complex over time, which can be obtained from the process of differentiation of cells, body tissues, organs and their organized systems. Child development consists of physical, cognitive, emotional, language, motor (gross and fine),

social and adaptive personal development. According to Frankerburg (1961) there are four aspects of the development of children under five, namely personality, fine motor skills, gross motor skills and language. ${ }^{14}$ To assess children's development, an assessment was carried out using the Developmental PreScreening Questionnaire (KPSP) covering the development of personality, fine motor skills, gross motor skills and language adjusted to the age of the child concerned. In the sample, the Developmental PreScreening Questionnaire (KPSP) covering the development of personality, fine motor skills, gross motor skills and language adjusted to the age of the child concerned. In the sample, the development of preschoolaged children was measured using the KPSP method ${ }^{15}$

The study has some limitations. This is caused by examination based on the nutritional status on the body weight for age, while there are several other techniques that were related but not studied, such as: anthropometry, clinical, biochemical, and biophysical. Therefore, to optimize the results of research, these techniques can also be employed. In addition, the children also found it difficult to execute the directions, while the parents were very helpful in the research. Researchers did not examine several factors related to the development of preschool children such as stimulus provided by parents, family economic income, and 
parental education which limited the discussion of the study.

\section{Conclusion}

There is a relationship between nutritional status and development of preschool aged children in the working area of Puskesmas Batua Raya.

\section{Conflicts of Interest}

No potential conflict of interest relevant to this article was reported.

\section{Funding sources}

\section{Acknowledgments}

\section{References}

1. Christiari Ayu Yuniko. Ramzi S.\& Irawan F. Hubungan Pengetahuan Ibu Tentang Stimulasi Dini Dengan Perkembangan Motorik Pada Anak Usia 6 - 24 Bulan Di Kecamatan Mayang Kabupaten Jember. Jurnal Universitas Jember, 1-3 (2013)

2. Hadi, Selasih Putri. Hubungan Status Gizi Dengan Perkembangan Motorik Pada Anak Usia 12 - 36 Bulan Didesa Sambirijo, Kecamatan Bringin, Kabupaten Semarang. 1(2).(2019)

3. Wauran, Chindy Gabriella. Rina Kundre. Wico S. Hubungan Status Gizi dengan Perkembangan Motorik Kasar pada Anak Usia 1-3 Tahun di Kelurahan Bitung Kecamatan Amorang Kabupaten Minahasa Selatan., e- journal Keperawatan, 4 (2), 1-7 (2016)

4. Rencana Kerja tahun 2018. Dinas Kesehatan Provinsi Sulawesi Selatan.

5. Kemenkes. Data dan Informasi Profil Kesehatan Indonesia 2018. Jakarta: Kementerian Republik Indonesia.( 2018)

6. Dinas Kesehatan Kota Makassar. http://dinkeskotamakassar.com/index.php/2017-02-09-09-30-56\# (2019.)

7. Septiani Rizki et al. Tingkat Perkembangan Anak Pra Sekolah Usia 3- 5 tahun yang mengikuti dan tidak mengikuti pendidikan Anak Usia Dini (PAUD). Semarang: Universitas Muhammadiyah semarang (2016)

8. Nurhabib. Hubungan Status Gizi dengan Perkembangan Anak Usia 3-4 tahun di Wilayah Kerja Puskesmas Pembina Palembang. Palembang: Universitas Muhammadiyah Palembang (2015)

9. Kusuma, Hubungan tingkat pengetahuan ibu tentang tumbuh kembang anak dan perkembangan motorik halus balita diwilayah kerja puskesmas penumping Surakarta. Surakarta: Universitas Muhammadiyah Surakarta (2013).

10. Ash-Siddiq. Penyakit infeksi dan Pola Makan dengan Kejadian Status Gizi Kurang berdasarkan BB/U pada balita usia 6-24 bulan di wilayah kerja puskesmas tanah sepanggal. Jambi: Universitas Adiwangsa

11. Departemen Agama RI. Al-Qur'an dan Terjemahannya. Bandung: PT. Syamsil Cipta Media. (2013)

12. Shihab, M. Quraish. Tafsir Al-Mishbah Volume 1. Tangerang: PT. Lentera Hati . (2016)

13. Supariasa, IND (2016). Penilaian status gizi pada anak. Jakarta: EGC

14. Soetjiningsih. Tumbuh Kembang Anak. Jakarta: EGC (2015).

15. Mustagfirah lailatul. Indah Risnawati Survey perkembangan balita menggunakan kuisioner praskrinning perkembangan (KPSP). Jurnal elektronik, 8(1) 46-9. (2018). 